\title{
Glutamic Acid Decarboxylase 2 Antibody Measurement
}

National Cancer Institute

\section{Source}

National Cancer Institute. Glutamic Acid Decarboxylase 2 Antibody Measurement. NCI

Thesaurus. Code C82017.

The determination of the amount of glutamic acid decarboxylase 2 antibody present in a sample. 